\title{
Influencia del contenido en cemento en la corrosión de la armadura en morteros carbonatados
}

\section{Cement content influence in rebar corrosion in carbonated mortars}

\author{
P. O. AMÉRICO, A.A. NEPOMLCENO
}

("Depto. de Engenharia Civil e Ambiental. Faculdade de Tecnologia . Universidade de Brasília

Fecha de recepción: 15-XII-02

Fecha de aceptación: 9-IV-03

BRASIL

\section{RESUMEN}

Los productos de hidratación del cemento protegen las armaduras embebidas en el hormigón debido a la gran cantidad de $\mathrm{Ca}(\mathrm{OH})_{2}$, NaOH y $\mathrm{KOH}$ disueltos en la fase acuosa del hormigón que proporcionan un $\mathrm{pH}$ mayor que 12,5. Sin embargo, las estructuras de hormigón armado están expuestas a los gases contaminantes como el $\mathrm{CO}_{2}$ que al penetrar en el hormigón reacciona con los compuestos alcalinos, se reduce el pH de la fase acuosa y provocan la despasivación de la armadura. Posteriormente, si hay disponibilidad de humedad y oxigeno empieza la corrosión.

El objetivo del presente trabajo es analizar la influencia del contenido en cemento, en la corrosión de armaduras en medios carbonatados empleando la técnica de Resistencia de polarización para la determinación de la intensidad de corrosión. Se presentan resultados de intensidad de corrosión de armaduras embebidas en probetas prismáticas de mortero fabricadas con tres dosificaciones de cemento con igual relación aguacemento. También se emplearon probetas cilindricas para medidas de absorción capilar antes y después de la carbonatación. Las caracteristicas de porosidad fueron evaluadas por porosimetría de intrusión de mercurio antes y después de la carbonatación.

Los resultados muestran que cuando el contenido en cemento disminuye el periodo de iniciación es menor y la intensidad de corrosión en la propagación mayor: Sin embargo, también hay una alteración de la microestructura con los cambios en la cantidad de cemento, lo que impide afirmar que la reserva alcalina aisladamente sea la responsable de estos resultados.

\begin{abstract}
SUMMARY
The cement hydration products protect the concrete rebars of the reinforced concrete due to the production of $\mathrm{Ca}(\mathrm{OH})_{2}$, $\mathrm{NaOH}$, and KOII that, upon dissolving in the concrete's aqueous phase, generate a pII above 12,5. However, reinforced concrete structures are exposed to pollutant gases, such as, $\mathrm{CO}$, which upon penetrating the concrete, reacts with the alkaline components, consequently reducing the $\mathrm{pH}$ of the aqueous phase causing the loss of passivity by the rebar and as a consequence its corrosion when there is the presence of humidity and oxygen.
\end{abstract}

The objective of the current paper is the analysis of the alkaline reserve influence, measured by the cement content, in the corrosion of rebars employing the polarization resistance technique for determining the corrosion intensity. Results for corrosion intensity of rebars embedded in prismatic mortar test specimens are produced with three cement content levels, with equal watericement ratio. Cylindrical test specimens were also used for verification of the capillary absorption and the porosity by means of mercury porosymetry.

The results show that the initiation period is shorter and the corrosion intensity of the rebars is higher when the cement content is lower: However; there is also an alteration in the microstructure upon altering the cement content, and for this reason one cannot conclude that the alkaline reserve alone is responsible for these results.
PALABRAS CLAVE: contenido en cemento. microestructura, carbonatación, intensidad de corrosión. porosimetría por intrusión de mercurio.
KEYWORDS: cement content. microstructure, c'arbonation, corrosion rate, mercury porosimetry. 


\section{INTRODUCCIÓN}

El hormigón contiene substancias resultantes de la hidratación como el $\mathrm{Ca}(\mathrm{OH})_{2}$ y los hidróxidos de sodio y potasio, que garantizan una alta concentración de $\mathrm{OH}^{-}(1)$, haciendo que el pH de la fase acuosa sea superior a 12,5. El hidróxido de calcio que constituye 20 a $25 \%$ del volumen de sólidos de la pasta de cemento hidratado (2) tiene una disolución en la fase acuosa controlada por la concentración de álcalis que son mucho más solubles. Este ambiente alcalino es lo que garantiza la estabilidad de las armaduras en el interior del hormigón. Sin embargo, el pH de la fase acuosa puede disminuir debido a las reacciones del $\mathrm{Ca}(\mathrm{OH})_{2}$ con el $\mathrm{CO}_{2}$ presente en el ambiente, que penetra por difusión en los poros del hormigón. Cuando el pH llega a ser próximo a 9,5, las armaduras pierden la pasividad.

Las armaduras pueden corroerse una vez despasivadas si hay humedad suficiente para desarrollar el proceso electroquímico de la corrosión (1). La porosidad es un factor determinante en los mecanismos de penetración de agentes agresivos hacia el interior del hormigón y, por ello, aquello que influye en las caracteristicas de los poros, altera la velocidad de penetración del $\mathrm{CO}_{2}$ (relación a/c, curado, aditivos, adicciones, etc.). Sin embargo, en la literatura se encuentra que la reserva alcalina controla también la velocidad de penetración del $\mathrm{CO}_{2}$. Así, según Tuutti (1) cuanto mayor sea la reserva alcalina del hormigón, mayor será el tiempo necesario para la reducción del $\mathrm{pH}$ junto a la armadura. El modelo de vida útil de Tuutti (1), para las estructuras de hormigón armado define dos fases: el período de iniciación, cuando tiene lugar la penetración del $\mathrm{CO}_{2}$ hasta la armadura con su consecuente despasivación, y el período de propagación en el cual la intensidad de corrosión de la armadura está controlada por la humedad y la disponibilidad de oxígeno. Existen varios modelos de predicción de la profundidad de carbonatación como el de Tuutti (1), Hamada (3) y de Papadakis et al. (4) y todos ellos consideran la porosidad y la reserva alcalina, definidas por la relación agua/cemento y el contenido y tipo de cemento. Es importante resaltar que estos modelos son herramientas que permiten calcular el periodo de iniciación pero no dan ninguna información sobre la intensidad de corrosión en el período de propagación de la corrosión.

El aumento de la reserva alcalina del hormigón es posible cuando se utiliza un mayor contenido en cemento y cementos con bajos contenidos de adiciones. Sin embargo, el aumento del contenido en cemento genera también alteración de la microestructura con la reducción de interconexión de la zona de transición existente en la interfase pasta de cemento/árido (5), que es más porosa que las demás fases de la microestructura

\section{INTRODUCTION}

Concrete contains substances resulting from hydration such as $\mathrm{Ca}(\mathrm{OH})_{2}$ and the sodium and potassium hydroxides, which assure a high concentration of $\mathrm{OH}^{-}$ (1), generating a $\mathrm{pH}$ value higher than 12.5 in the aqueous phase. The calcium hydroxide, which makes up 20 to $25 \%$ of the solid volume in the hydrated cement matrix (2) has its dissolution in the aqueous phase controlled by an elevated concentration of alkalis that are much more soluble. The alkaline environment guarantees the stability of the rebars inside the concrete. However, the $\mathrm{pH}$ in the aqueous phase tends to decrease, due to the carbonation reactions, caused by the presence of $\mathrm{CO}_{2}$ in the environment that penetrates by diffusion through the pores in the concrete. When the $\mathrm{pH}$ gets close to 9.5, the rebars lose their passivity.

Once having lost the passivity, the rebars may be subject to corrosion as long as there is enough humidity to develop the electrochemical process of corrosion (1). The porosity is the determining factor in the transport mechanisms for the agents aggressive to the concrete's interior, and hence all factors that influence the pore characteristics alter the $\mathrm{CO}_{2}$ penetration velocity (water/cement ratio, curing, admixtures, additions, etc.). However, the $\mathrm{CO}_{2}$ penetration velocity is controlled, amongst other things, by the alkaline reserve. Thus, the higher the alkali reserve in the cement, the longer the time necessary for the $\mathrm{pH}$ reduction at the rebars (1). The Tuutti service life model (1) for reinforced concrete structures define two distinct phases: the initiation period, when there is $\mathrm{CO}_{2}$ penetration until the rebar with its consequential loss of passivity, and the propagation period when the rebar corrosion intensity is controlled by the availability of humidity and oxygen. Various models for prediction of carbonation depth such as those of Tuutti (1) Hamada (3) and Papadakis et al. (4), take into consideration the porosity and the alkaline reserve, by means of the water/cement ratio and the cement content and type, amongst other parameters. One must point out that these models are tools allowing for calculation of the initiation period, but do not give information on the corrosion intensity during the corrosion propagation period.

The increase in the concrete's alkaline reserve is possible by the use of more cement and by the employment of cements with low addition levels. However, this increase in cement content also generates an alteration to its microstructure, due to the reduction in the transition zone (5), which is more porous than the other concrete microstructure phases and the increasing in the cement paste volume, usually 
del hormigón (2). La pasta de cemento, a su vez, tiene generalmente un mayor volumen de poros que el árido. Por esta complejidad de factores hay en la literatura una gran cantidad de trabajos con morteros y hormigones con resultados contradictorios en relación a la velocidad de carbonatación, permeabilidad a gases y movimiento de agua, cuando se cambia el contenido en cemento (6-9). Mientras tanto, son pocos los trabajos sobre la capacidad de protección de hormigones y morteros con distintas cantidades de reserva alcalina, frente a la carbonatación con evaluación simultánea de la corrosión de las armaduras (10).

La técnica electroquímica de resistencia de polarización $(\mathrm{Rp})$ es la más empleada para medir la intensidad de corrosión de armaduras embutidas en probetas (10, 11, 12 y 14) y por esto fue empleada en el presente trabajo. Se evaluó la influencia del contenido en cemento en el comportamiento de barras de acero embebidas en morteros durante el proceso de carbonatación y, posteriormente, en presencia de agua. Se empleó también la técnica de porosimetría por intrusión de mercurio y absorción capilar para evaluar la alteración de la microestructura con el aumento del volumen de áridos en morteros con distintos contenidos en cemento antes y después de la carbonatación.

\section{PROCEDIMIENTO EXPERIMENTAL}

Para estudiar la influencia de la reserva alcalina en el período de iniciación y en la velocidad de propagación de la corrosión de armaduras fueron moldeadas probetas de mortero de cemento portland con arena, con 4 barras de acero de $5 \mathrm{~mm}$ de diámetro, con una relación agua/cemento igual a 0,6. La arena empleada es de origen fluvial, de la región de Brasilia-Brasil, tiene un módulo granulométrico de 3,0 y tamaño máximo de 4,8 mm (13).

Se empleó un cemento CPII F-32 de fabricación brasileña, con una superficie específica de $317 \mathrm{~g} / \mathrm{cm}^{3}$. Su composición química se presenta en la Tabla 1. Para los ensayos de corrosión se fabricaron 2 probetas

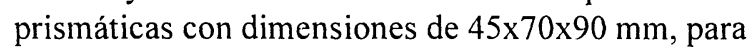
cada contenido en cemento y con dos barras para cada recubrimiento ( 10 y $20 \mathrm{~mm}$ ). Para los ensayos de absorción capilar y medidas de profundidad de carbonatación fueron moldeadas probetas cilíndricas de with a greater pore volume than the aggregate. Due to this complexity of factors one finds in the literature various papers displaying contradicting results in terms of carbonation velocityy concrete and mortar permeability to gases and humidity, related to cement content (6-9). However, there are few papers on the protection capacity of concrete and mortars, with different quantities of alkaline reserves, facing carbonation with corrosion evaluation of rebars embedded in the test specimens (10).

The electrochemical polarization resistance technique (Rp) is already employed successfully to evaluate the corrosion intensity of the rebars embedded in test specimens (10,11,12 and 14) and for this reason was utilized in this work. The cement content influence was evaluated in the behavior of steel rods soaked in mortars during the carbonation process and later in the presence of water. The mercury porosymetry and capillary absorption technique was also used to evaluate the microstructure change with the increase in the volume of aggregates at different cement content levels before and after carbonation.

\section{EXPERIMENTAL PROCEDURE}

To study the influence of the alkaline reserve in the rebar corrosion rate during the initiation and propagation periods, portland cement with medium sand mortar test specimens were molded, with four $5 \mathrm{~mm}$ steel rods, with the water/cement ratio equal to 0.60 . The sand used is of fluvial origin from the Brasilia-Brazil region and has grain size module of 3.0 with maximum size of $4.8 \mathrm{~mm}$ (13).

The cement utilized was the CPII F-32 manufactured in Brazil with a specific surface area of $317 \mathrm{~g} / \mathrm{cm}^{3}$ with the chemical composition shown in Table 1. For the corrosion tests 2 prismatic test specimens were molded with the dimensions of $45 \times 70 \times 90 \mathrm{~mm}$ for each cement content level each containing two rebars at each covering level (10 and $20 \mathrm{~mm}$ ). For the complementary capillary absorption tests and carbonation depth measurements, cylindrical test specimens were molded

TABLA $1 /$ TABLE 1

Composición química del cemento

Chemical composition of the cement

\begin{tabular}{|c|c|c|c|c|c|c|c|c|c|c|}
\hline $\mathrm{SiO}_{2}$ & $\mathrm{CaO}$ & $\mathrm{Fe}_{2} \mathrm{O}_{3}$ & $\mathrm{Al}_{2} \mathrm{O}_{3}$ & $\mathrm{SO}_{3}$ & $\mathrm{MgO}$ & $\begin{array}{c}\mathrm{CaO} \\
\text { libre }\end{array}$ & $\mathrm{Na}_{2} \mathrm{O}$ & $\mathrm{K}_{2} \mathrm{O}$ & $\mathrm{PF}$ & $\mathrm{RI}$ \\
\hline 17,91 & 59.91 & 2.90 & 4.53 & 3,00 & 3.23 & 1.18 & 0.20 & 0.83 & 4.45 & 0.79 \\
\hline
\end{tabular}


$50 \mathrm{~mm}$ de diámetro y $100 \mathrm{~m}$ de altura en conformidad con las prescripciones brasileñas. Las probetas se curaron durante 28 días. Al término del curado, las probetas se dejaron en ambiente de laboratorio hasta la estabilización de masa (13).

La edad de las probetas cuando se empezaron los ensayos de corrosión de la barras, cra de 75 a 94 días, lo que disminuye la influencia del grado de hidratación del cemento en los resultados.

Para los ensayos de carbonatación se empleó una cámara de carbonatación con $\mathrm{CO}_{2}$ al $100 \%$ en cuatro ciclos diarios. Los ciclos se construyeron de un flujo continuo de $5 \mathrm{l} / \mathrm{min}$ durante 10 minutos y 2 horas más en la cámara de carbonatación. Al final de cada ciclo se midicron las variables electroquímicas y la masa de las probetas. Por la noche las probetas permanecieron en la cámara sin $\mathrm{CO}_{2}$ hasta cl día siguiente, cuando se reiniciaron los ciclos. La humedad relativa dentro de la cámara permaneció entre el 50 y $70 \%$. En total se hicieron 28 medidas electroquímicas de intensidad de corrosión además de potencial de corrosión y resistencia óhmica que son presentadas en otro trabajo (13). Durante el ensayo se midió también la profundidad de carbonatación en las probetas cilíndricas empleando disolución de fenoltaleína al $1 \%$. Inmediatamente después de la carbonatación, las probetas empleadas en el ensayo de corrosión fucron puestas en diversas condiciones de humedad de acuerdo con la Tabla 3. with $50 \mathrm{~mm}$ in diameter and $100 \mathrm{~mm}$ in height following the Brazilian norm. The test specimens were cured for 28 days. After the curing, the test specimens remained within the lab environment until the mass stabilized (13).

The rebar corrosion evaluation tests, with the prismatic test specimens, were carried out at ages between 75 and 94 days to diminish the influence of the hydration level.

A carbonation chamber with a $\mathrm{CO}_{2}$ flow of $100 \%$ was employed during 10 minutes with a flow-rate of $5 \mathrm{l} / \mathrm{min}$, and wo more hours in the carbonation chamber. At the end of each cycle the electrochemical and mass variation measurements were taken. During the night the test specimens remained in the chamber without $\mathrm{CO}_{2}$ until the next day; when the cycles started once again. The relative humidity inside the chamber remained between 50 and $70 \%$. The electrochemical corrosion intensity and mass variation measurements were made for 28 cycles, besides other variables not dealt with in this paper (13). Carbonation in the cylindrical test specimens was also measured using phenolphthalein dissolution at 1\%. Immediately after carbonation, the test specimens used in the evaluation tests were put in various humidity conditions according to Table 3.

TABLA 2/TABLE 2

Dosificación de los morteros

Mortar characteristics

\begin{tabular}{|c|c|c|c|c|c|}
\hline $\begin{array}{l}\text { GRUPO } \\
\text { GROUP }\end{array}$ & $\begin{array}{c}\text { CONTENIDO } \\
\text { EN CEMENTO } \\
\left(\mathrm{kg} / \mathrm{m}^{3}\right) \\
\text { CEMENT } \\
\text { CONTENT } \\
\left(\mathrm{kg} / \mathrm{m}^{3}\right) \\
\end{array}$ & $\begin{array}{l}\text { PROPORCIÓN } \\
\text { Cemento:Arena } \\
\text { PROPORTION } \\
\text { Cement/Sand }\end{array}$ & $\begin{array}{l}\text { VOLUMEN } \\
\text { DE ÁRIDO } \\
(\%) \\
\text { AGGREGATE } \\
\text { VOLUME } \\
(\%)\end{array}$ & $\begin{array}{c}\text { RELACIÓN } \\
\text { AGUA/MATERIALES } \\
\text { SECOS }(\%) \\
\text { WATER/DRY } \\
\text { MATERIAL RATIO } \\
(\%) \\
\end{array}$ & $\begin{array}{c}\text { CONSISTENCIA } \\
(\mathrm{mm}) \\
\text { CONSISTENCY } \\
(\mathrm{mm})\end{array}$ \\
\hline G4 & 445 & $1: 3,47$ & 58,90 & 13.43 & 225 \\
\hline G5 & 545 & $1: 2,39$ & 49,71 & 17.71 & 330 \\
\hline G6 & 645 & $1: 1,64$ & 40,37 & 22,71 & - \\
\hline
\end{tabular}

TABLA 3/TABLE 3

Duración de las ctapas del cnsayo de corrosión con probctas prismáticas Duration of the stages in the evaluation test for corrosion with prismatic test specimens

\begin{tabular}{|c|c|c|c|c|c|c|}
\hline $\begin{array}{l}\text { ETAPA } \\
\text { STACI: }\end{array}$ & $\begin{array}{l}\text { CARBONAT. } \\
\text { CARBONAT. }\end{array}$ & $\begin{array}{l}\text { PARCIALMENTE } \\
\text { SUMERGIDA (1) } \\
\text { PARTLLLY } \\
\text { SUBMIER(ILI) (I) }\end{array}$ & 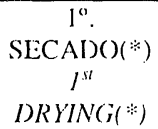 & $\begin{array}{l}\text { PARCIALMENTE } \\
\text { SUMERGIDA (2) } \\
\text { PARTIALLY } \\
\text { SUBMER(ILI) (2) }\end{array}$ & $\begin{array}{c}2^{\circ} . \\
\operatorname{SECADO}(*) \\
2^{\text {nd }} \\
\text { DRYING(:)}\end{array}$ & $\begin{array}{l}100 \% \\
\text { HR(3) } \\
100 \% \\
H R(3)\end{array}$ \\
\hline $\begin{array}{l}\text { DURACIÓN } \\
\text { (dias) } \\
\text { DURATION } \\
\text { (days) }\end{array}$ & 10 & 5 & 7 & 7 & 7 & 19 \\
\hline
\end{tabular}

"Estos períodos no se representan el los resultados.

"These periods are not shown in the results. 
Los ensayos de absorción capilar fueron realizados en conformidad con las prescripciones brasileñas (NBR 9779-95), utilizando probetas cilíndricas carbonatadas y no carbonatadas.

Después de realizados los ensayos se tomaron las muestras para caracterización de la porosidad empleando la técnica de porosimetría por intrusión de mercurio (PIM). Las muestras no carbonatadas fueron retiradas de las probetas cilindricas mientras que las muestras carbonatadas se extrajeron de las probetas prismáticas entre las dos barras de acero estudiadas. Se empleó un porosímetro marca Micrometrics, modelo Autopore III. Los ensayos se realizaron después del secado de las muestras durante 24 h en estufa al vacío y temperatura de $100^{\circ} \mathrm{C}$. Las presiones aplicadas variaron de 0,54 a 4,45 psi y el ángulo de contacto fue considerado igual a $130^{\circ}$.

Para las medidas electroquímicas de Resistencia de polarización_(Rp) se emplearon los procedimientos de otros trabajos (10-12). El potenciostato utilizado fue desarrollado en el Departamento de Ingeniería Eléctrica de la Universidad de Brasilia y ha sido empleado en anteriores trabajos (12, 14 y 15).

\section{RESULTADOS}

Las Figuras la y $1 \mathrm{~b}$ presentan los resultados de las medias de la intensidad de corrosión de las barras puestas a $20 \mathrm{~mm}$ de la superficie de las probetas para los tres contenidos de cemento, durante la carbonatación acelerada. Los resultados de la intensidad de corrosión de las barras con $10 \mathrm{~mm}$ de recubrimiento se presentan en (13) y son semejantes a los obtenidos para los recubrimientos de $20 \mathrm{~mm}$. La región entre $0,1-0,2 \mu \mathrm{A} / \mathrm{cm}^{2}$, según Andrade et al. (11), es considerada la región límite de despasivación. Intensidades de corrosión por encima de estos valores
The capillary absorption tests were carried out according to the Brazilian norm NBR 9779-95, using carbonated and non-carbonated cylindrical test specimens.

After finishing the tests, samples of the test specimens were taken for characterizing the porosity by means of mercury porosymetry. The samples without carbonation were taken from the test specimens used in capillary absorption and the carbonated ones were removed from the test specimens used for corrosion evaluation, between the two rods. A Micromeritics, Autopore III model porosymeter was utilized. The tests were carried out after drying the test specimens during 24 hours in a vacuum furnace, maintained at the temperature of $100^{\circ} \mathrm{C}$. The pressures applied varied between 0.54 psi and 4.45 psi and the contact angle considered was $130^{\circ}$.

For the electrochemical measurements polarization resistance measurements procedures $(R p)$ were used, according to various studies (10-12). The potentiostat used was developed by the Brasilia University Electrical Engineering Department and used in various other previous works (12,14 and 15).

\section{RESULTS}

The analysis of the influence of cement content was carried out by means of corrosion intensity, capillary absorption, mercury porosymetry, besides mass variation measurements. Figures $1 a$ and $1 b$ show the results for average corrosion intensities of the rods embedded at $20 \mathrm{~mm}$ from the test specimens surface for the three cement content levels, during the carbonation. The results for the rods embedded at $10 \mathrm{~mm}$, are not included in this work, but are similar to those obtained for $20 \mathrm{~mm}$ (13). The region between 0.1-0.2 $\mathrm{A} / \mathrm{cm}^{2}$, according to Andrade et al. (11) is considered to be the

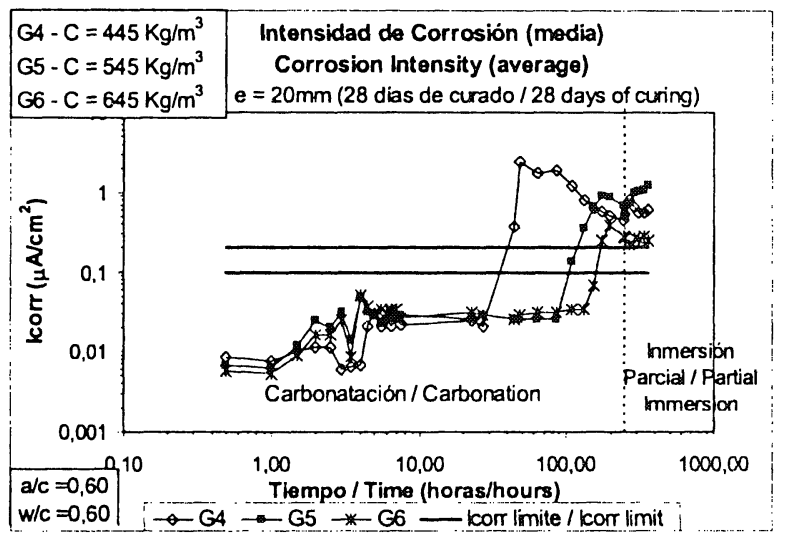

(a)

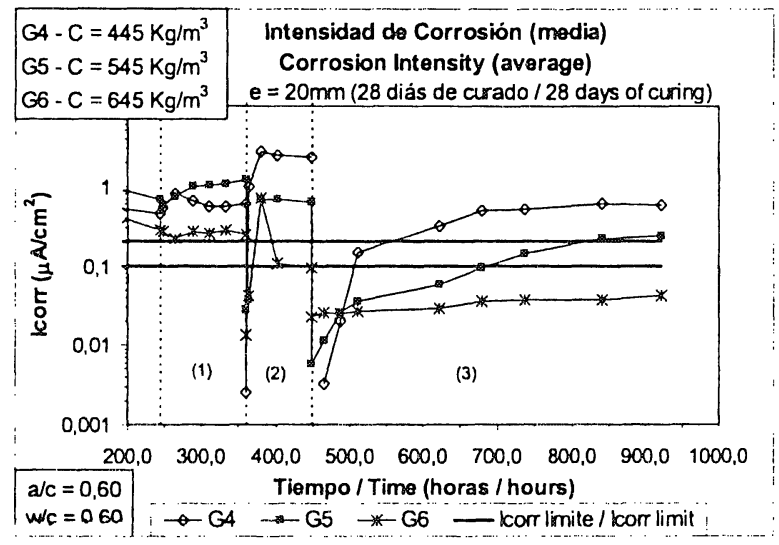

(b)

Figura 1.- Variación de la intensidad de corrosión: a) durante la carbonatación; b) en distintas condiciones de humedad.

Figure 1.- Corrosion intensity variation: a) during the carbonation; b) at the various humidity conditions 
son consideradas importantes para la vida útil de las estructuras. Durante la carbonatación las intensidades de corrosión embebidas en los morteros con 445, 545 y $645 \mathrm{~kg} / \mathrm{m}^{3}$ de cemento pasan la región límite a las 40,150 y 180 horas, respectivamente, indicando que cuanto mayor es el contenido en cemento ${ }_{2}$ mayor es el período de iniciación.

En este período, las intensidades de corrosión son también inversamentc proporcionales al contenido en cemento: las intensidades más elevadas ocurren en las probetas con contenido en cemento más bajos. En las diversas condiciones de humedad a que se sometieron las probetas, las mayores intensidades de corrosión también ocurrieron en las barras que estaban embebidas en menores contenidos de cementos, excepto inmediatamente después de la carbonatación (Figura 1b (1)). limiting region for loss of passivity: Corrosion intensities above these values are considered important for the structure service life. During the carbonation, the corrosion intensities embedded in the mortars with 445, 545 , and $645 \mathrm{~kg} / \mathrm{m}^{3}$ of cement surpass the limit region at 40,150 , and 180 hours respectively, indicating that the higher the content the bigger the initiation period.

During the carbonation, the corrosion intensities are inversely proportional to the cement content, i.e., greater intensities occurred in test specimens with lower cement content. At the various humidity conditions at which the test specimens were placed, the greater corrosion intensities occurred also in test specimens with a lower consumption of cement, except soon after carbonation (Figure $1 b(1)$ ).

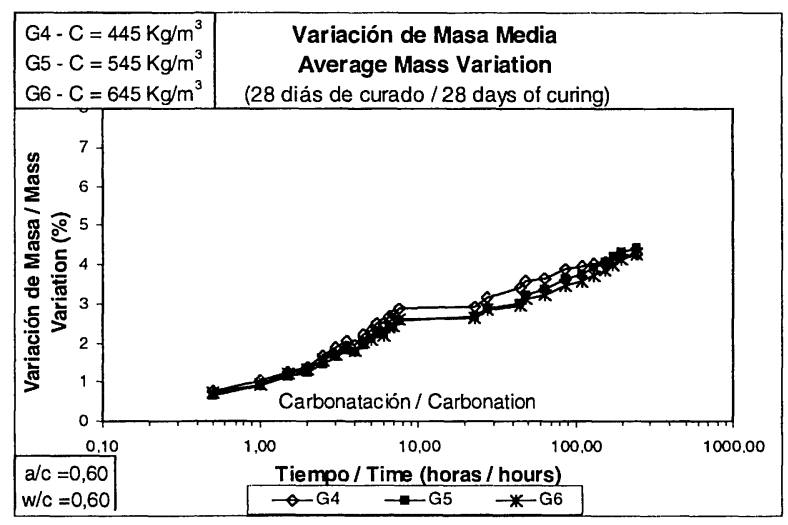

(a)

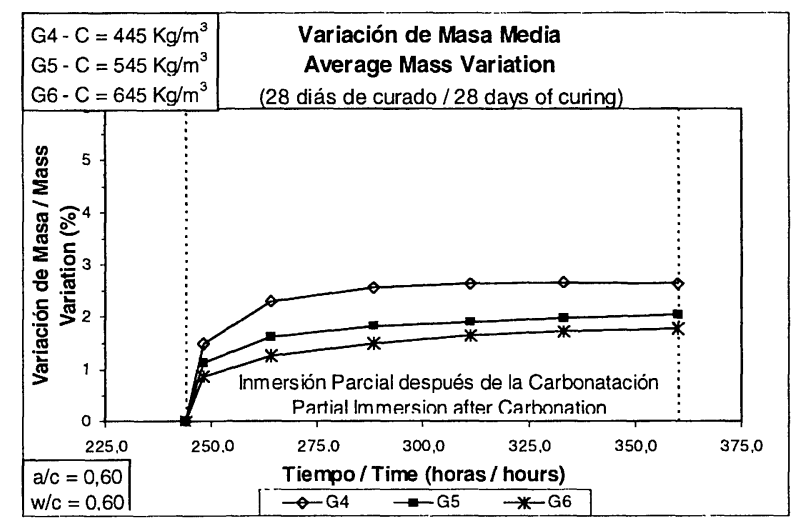

(b)

Figura 2.- Variaciones de masa de las probetas prismáticas: a) durante la carbonatación y b) inmersión parcial sin secado.

Figure 2.- Prismatic test specimens mass variations: a) during the carbonation and b) partially submerged without drying.

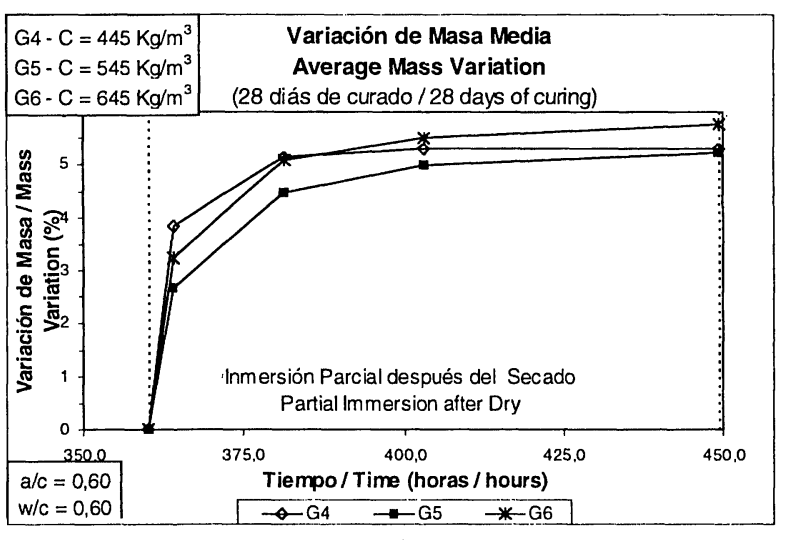

(a)

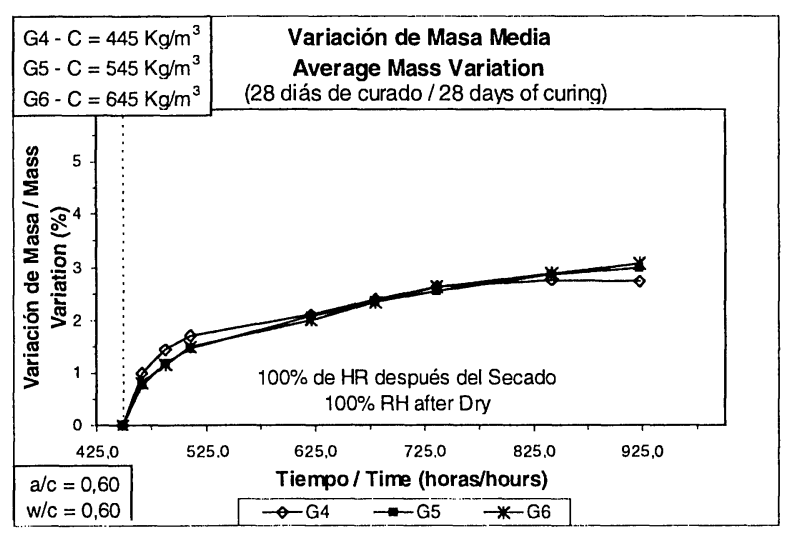

(b)

Figura 3.- Variacion de masa: a) inmersión parcial después del secado y b) $100 \%$ HR después del secado.secado.

Figure 3.- Mass variation: a) partially submerged after drying and b) 100\% RH after drying. 
En las Figuras 2 y 3 se presentan las variaciones porcentuales de masa de las probetas en relación a la masa inicial de las probetas en cada etapa del ensayo. Durante la carbonatación prácticamente no hay diferencia de aumento de masa para los tres contenidos en cemento aunque hay una tendencia de mayor aumento en las probetas con menor contenido en cemento. El aumento de masa en la condición de inmersión parcial inmediatamente después de la carbonatación (Figura $2 b(1)$ ) muestra mayor absorción para los menores contenidos de cemento. Como se esperaba, después del primer secado (Figura 3a (2)), cuando el agua generada en el proceso de carbonatación probablemente se elimina, hay una mayor absorción de agua en todas las probetas y las probetas de mayor contenido en cemento presentan una mayor absorción al fin del ensayo. Después del segundo secado, en la condición de $100 \%$ de humedad (Figura 3b (3)), la absorción de vapor de agua es igual para todas las probetas con los distintos contenidos de cemento.

Los resultados de absorción de las probetas prismáticas se muestran en la Figura 4, donde se observa que mayores contenidos de cemento proporcionan mayor absorción capilar antes y después de la carbonatación. Se aprecia también en este ensayo que la absorción capilar en todas las probetas con los distintos contenidos en cemento después de la carbonatación disminuyen pero se mantiene la misma tendencia antes de la carbonatación. La Figura 5 nos enseña la profundidad de carbonatación medida en las probetas cilíndricas donde se aprecia que los morteros con menor contenido en cemento se carbonatan más rápidamente. Los resultados de

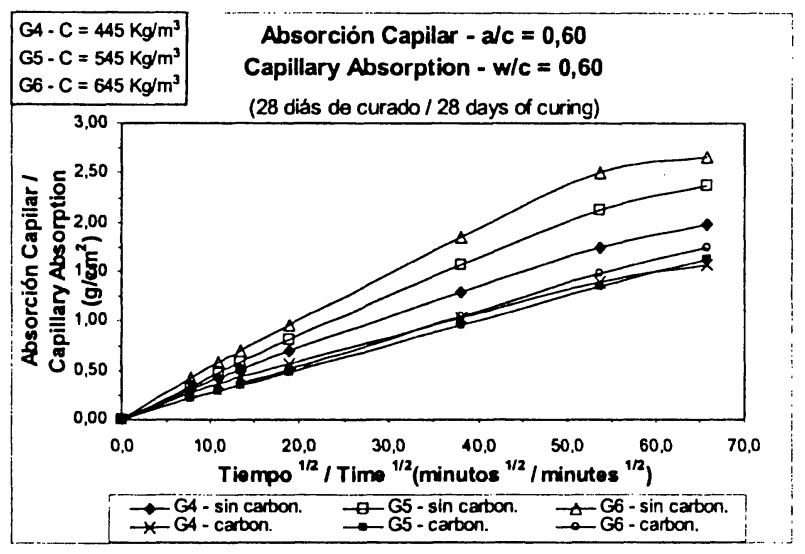

Figura 4.- Absorción capilar antes y después de la carbonatación para las probetas cilindricas.

Figure 4.- Capillary absorption before and after carbonation.
Figures 2 and 3 show the mass variations of the test specimens during the whole test. During the carbonation there is practically no difference in the mass increase for the three consumption levels, although there is a tendency for a greater increase in the test specimen with lower cement content. Soon after the carbonation one notices a direct correspondence between the absorption and the cement content (Figure $2 b(1)$ ). It is observed that after the first drying (Figure $3 a(2)$ ), there is greater water absorption, as expected, since the carbonation process generates internal humidity, causing difficulties in the penetration of water by absorption, when this water does not migrate to the exterior. However, the tendency for greater absorption for lower cement content ceases to exist, although the test specimens with higher cement content have higher absorption at the end of the test. After the second drying, with 100\% humidity (Figure $3 b(3))$, water vapor absorption is equal for all test specimens with different cement content.

These absorption results for prismatic test specimens are shown in Figure 4, where one observes that the higher cement content generates a higher capillary absorption before and after carbonation. One notices also that in this test the capillary absorption at all cement content levels decreases after carbonation but maintains the same trend of before carbonation. Figure 5 shows us the measured carbonation in the cylindrical test specimens where it can be observed that mortars with less cement content carbonate more

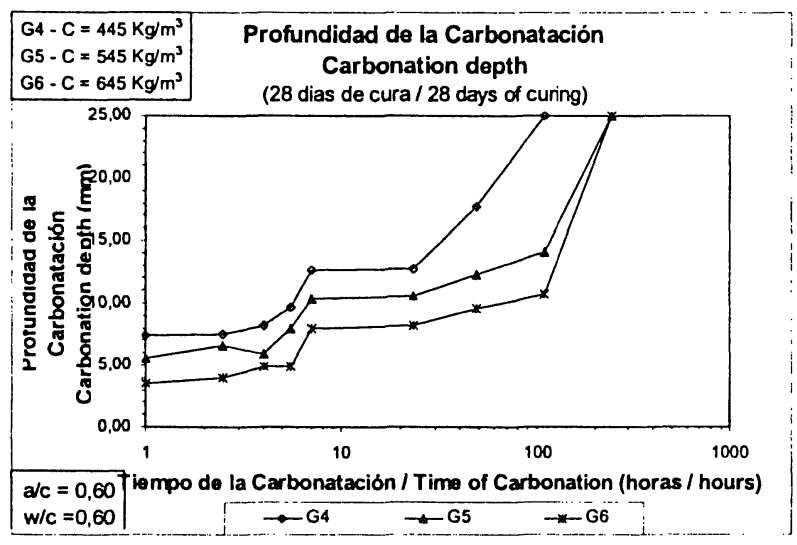

Figura 5.- Profundidad de carbonatación de probetas cilindricas con los tres contenidos de cemento.

Figure 5.- Carbonation depth in cilindrical specimens. 


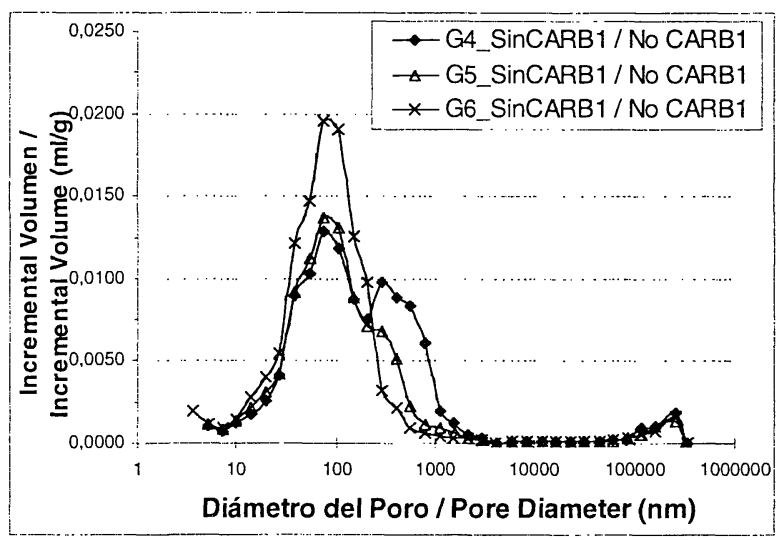

(a)

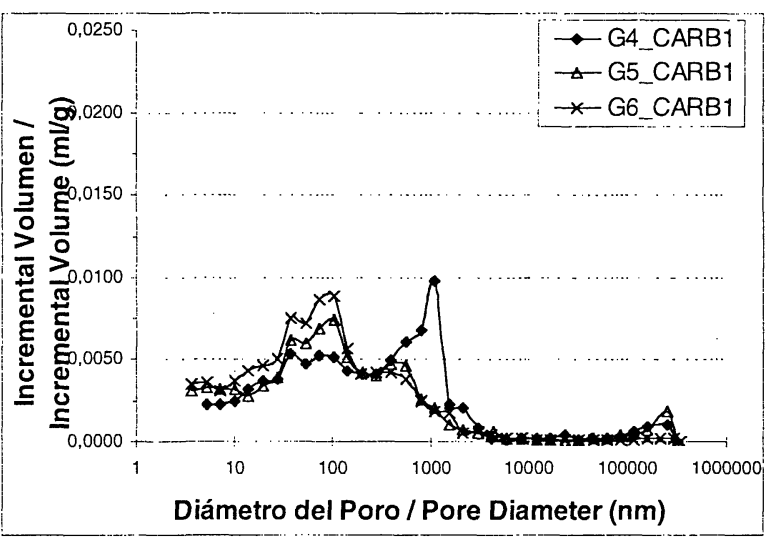

(b)

Figura 6.- I)istribución del tamaño de poros de los morteros con diferentes contenidos en cemento: a) no carbonatados; b) carbonatados.

Figure 6.- Pore size distribution curves for different cement content mortars: a) no carbonated: b) carbonated.

PIM (Figura 6a y 6b) muestran que hay un aumento de volumen de poros en el rango de 0,2 a $2 \mu \mathrm{m}$ cuando se disminuye el contenido en cemento, con el consecuente aumento del volumen de áridos (G4 e G5). Se observa también que hay un mayor volumen de poros menores que $0,2 \mu \mathrm{m}$ en el mortero con mayor contenido en cemento. Aunque hay una reducción en el volumen total de poros después de la carbonatación, se aprecia que la distribución de tamaño de poros tiene el mismo perfil anteriormente mencionado. El mayor volumen de poros menores que $0,2 \mu \mathrm{m}$ de los morteros con mayor contenido en cemento puede indicar el mayor volumen de poros de la pasta de cemento.

\section{DISCUSIÓN}

Los resultados de intensidad de corrosión indican que durante la carbonatación y en presencia de humedad, hay influencia del contenido en cemento en los valores medidos, para la relación agua/cemento estudiada.

Durante la carbonatación no hay diferencia significativa en el aumento de masa con los tres contenidos en cemento. Además de la despasivación mas rápida para las armaduras embebidas en morteros con menores contenidos en cemento, se midieron valores de intensidades mayores cuando todas las armaduras se despasivaron. La carbonatación medida en probetas cilíndricas también resultó en mayores profundidades al lo largo del tiempo para menores contenidos en cemento. El transporte de agua en las probetas también se presentó alterado con las modificaciones en el contenido en cemento antes y después de la carbonatación. Por ello, es innegable que, al alterarse las proporciones en cemento y árido, además de modificarse la reserva alcalina hay también un cambio en la microestructura de los morteros que influyen en las intensidades de corrosión. rapidly. The results for the mercury porosymetry test (Figures 6a and 6b) show an increase in pore quantity between 0.1 and $2 \mu \mathrm{m}$ when increasing the volume of aggregates (G5 and G6). Although there is a reduction in the pore quantity after carbonation, it is observed that the mortars with higher volumes of aggregates have a greater number of pores within the same size range mentioned above.

\section{DISCUSSION}

The results from the corrosion intensity clearly show, during carbonation and later with the presence of humidity, that there is cement content influence in the measured values for the water/cement ratio studied. During carbonation there is no significant mass increase in the three cement contents but, besides the more rapid loss of passivity for the embedded rebars in mortars with less cement content, larger intensity measures were measured when all rebars lost passivity. The carbonation measured in cylindrical test specimens also gave results of greater depth for smaller cement contents. Water transportation in the test specimens was also altered with the changes in cement content before and after carbonation. It is undeniable that by altering the cement and aggregate proportions, besides changing the alkaline reserve, there is also a change in the microstructure of the mortars that have influence over the intensities of corrosion. 


\subsection{Influencia del contenido en cemento en el proceso de carbonatación}

Según Winslow et al. (5), cuando se reduce el contenido en cemento y se aumenta el volumen de áridos en el mortero, hay mayor posibilidad de que exista conexión entre las diversas zonas de transición que se forman alrededor de los áridos. Estos investigadores, encontraron, empleando la técnica de PIM, que en morteros con relación $\mathrm{a} / \mathrm{c}=0,4$, un volumen de áridos variable entre 0 y $55,4 \%$ y con tamaño máximo de $4,8 \mathrm{~mm}$, se produjo un aumento de volumen de poros de mayores diámetros con el aumento en el contenido en áridos, lo que fue atribuido al aumento en la zona de transición.

En el presente trabajo, empleando volumen de áridos de $40,37,49,71$ y $58,9 \%$ puede observarse en los resultados de porosimetría por intusión de mercurio que cuando se aumenta la cantidad de áridos y se reduce el contenido en cemento, también hay un aumento del volumen de poros mayores. Sin embargo, durante la carbonatación, a pesar de la mayor velocidad de carbonatación medida en las probetas cilíndricas y de la despasivación mas rápida de las armaduras embebidas en los morteros con menor contenido en cemento, el aumento de la masa de las probetas prismáticas durante la carbonatación no presentó grandes diferencias para los distintos contenidos en cemento. Se proponen tres hipótesis: a) el $\mathrm{CO}_{2}$ pudo haber penetrado a través de la zona de transición, que puede tener mayor conexión cuando hay mayor volumen de árido, lo que proporcionó una mayor profundidad de carbonatación en las probetas de menor contenido en cemento promoviendo la despasivación más rápida de las armaduras; b) también se puede considerar que hay influencia de la reserva alcalina pues, al aumentarse el contenido en cemento, se proporciona mayor cantidad de $\mathrm{Ca}(\mathrm{OH})_{2}$, consumiéndose así el $\mathrm{CO}_{2}$ que penetra y por ello el frente de carbonatación avanza con dificultad; c) se debe considerar también que en las probetas con mayor contenido en cemento hay una mayor superficie específica de los poros proporcionada por la mayor cantidad de poros menores debido el mayor contenido en pasta. Esto supone mayor cantidad de reacciones generando en el interior de la probeta una mayor cantidad de agua. La dificultad de difusión de este agua para el exterior será mayor cuanto menores sean los poros conectados y, en este caso, se aumentará la masa durante la carbonatación acelerada. El aumento de agua dificultará también el proceso de difusión del $\mathrm{CO}_{2}$ reduciendo la profundidad de carbonatación. Esta última hipótesis está reforzada por la absorción capilar de las probetas prismáticas en condiciones parcialmente sumergidas realizada inmediatamente después de la carbonatación: aquéllas con mayores contenidos en cemento absorben menos agua pero

\subsection{Alkaline reserve influence in the carbonation process}

According to Winslow et al. (5), when a reduction in cement content takes place with an increase of aggregates in the mortar, there is larger possibility of having connections between the various transition zones formed around the aggregates. These researchers found, employing the mercury porosymetry technique that, in mortars with an water/cement ratio of 0.4 and an aggregate volume varying between 0 and $55.4 \%$, there was an increase in the quantity of larger pores, following the increase in the aggregate content, being attributed to the increase in the transition zone.

In this paper; we used aggregate volumes of $40.37,49.71$, and $58.9 \%$ observing, with the mercury porosymetry test, that upon increasing the quantity of aggregate (reducing the cement content), there is also an increase in the quantity of larger pores. However, during carbonation, notwithstanding the larger carbonation speed measured in the cylindrical test specimens and the quicker loss of passivity of the rebars embedded in the mortars with less cement content, the increase of the mass of the prismatic test specimens during carbonation did not present a large amount of differences for the different cement contents. Three hypotheses may be considered: a) The $\mathrm{CO}_{2}$ may have penetrated through the transition zone, which is larger for a larger volume of aggregate, generating a deeper carbonation, in the lower cement content test specimens promoting a more rapid loss of passivity in the rebars; b) one may also consider the phenomenon as an influence of the alkaline reserve, since, upon increasing the cement content, a larger quantity of $\mathrm{Ca}(\mathrm{OH})_{2}$ is present, consuming the $\mathrm{CO}_{2}$ that penetrates, thus, the carbonation front advances with greater difficulty; c) One must also consider, that in the test specimens with greater cement content, there is a larger specific surface of the pores generated by the higher quantity of smaller pores, which may cause a higher number of reactions generating in the interior a larger amount of water. The difficulty in diffusion of this water to the exterior will be higher, the smaller the interconnected pores are, increasing the mass during the accelerated carbonation process. The increase in water will also bring difficulties to the $\mathrm{CO}$, diffusion process reducing the carbonation depth. This last hypothesis is reinforced by capillary absorption of the prismatic test specimens partially submerged immediately after carbonation: those with larger cement content absorb less water but when dry and back to original condition, besides presenting larger 
cuando están secas y se ponen nuevamente en la misma condición, además de presentar mayor absorción, aquélla que tiene mayor contenido en cemento absorbe más agua. Es posible también que estos tres fenómenos hayan ocurrido

simultáneamente.

Los resultados de profundidad de carbonatación medidos en probetas cilíndricas están en conformidad con los modelos presentados por Tuutti (1) y por Papadakis el al. (4) en los cuales la velocidad de carbonatación es inversamente proporcional al contenido en cemento. Sin embargo, los resultados no reproducen lo obtenido por Buenfeld y Okundi (7) que obtuvieron mayores velocidades de carbonatación para mayores contenidos en cemento, para hormigones con una misma relación agua/cemento empleando carbonatación acelerada. Loo et al. (8) no encontraron diferencias de velocidad de carbonatación para hormigones con distintos contenidos en cemento con una misma relación agua/ cemento. Estos autores (7-8) también utilizaron la fenoltaleína para evaluar la carbonatación.

\subsection{Influencia del contenido en cemento en proceso de humectación}

Tras la carbonatación es la presencia de humedad la que controla la velocidad de corrosión. En el presente trabajo, la absorción de agua de las probetas prismáticas, donde estaban las armaduras, varió a medida que se hicieron los ciclos de humectación y secado pero las intensidades de corrosión, medidas en ambientes húmedos fueron siempre proporcionales al contenido en cemento. Esto ocurrió también en ambiente con $100 \%$ de humedad relativa cuando el aumento de masa debido la penetración de vapor de agua fue prácticamente igual para todas las probetas independiente del contenido en cemento. Los resultados sugieren la necesidad de investigar el mecanismo de transporte de agua hacia al interior de las probetas, con la variación del contenido en cemento.

Es importante considerar que este comportamiento puede justificarse también si las probetas con mayores contenidos en cemento no se carbonataron totalmente a pesar de la indicación de total carbonatación en las probetas cilíndricas con fenoltaleína. Cuanto esto ocurre en ambientes húmedos, el hidróxido de calcio no carbonatado se disuelve y difunde hacia la región de la armadura aumentando el $\mathrm{pH}$ de la fase acuosa y contribuyendo para una posible repasivación (1), lo que puede justificar los menores valores de intensidad de corrosión de armaduras en tales probetas. absorption capacity, the one with the largest cement content absorbs more water. It is possible that these three phenomena occurred at once.

The results obtained regarding the carbonation depth are in accordance with the models presented by Tuutti (1) and by Papadakis et al. (4), in which the cement content is inversely proportional to the carbonation depth. However, the results do not reproduce those found by Buenfeld \& Okundi (7) who, working with concrete and accelerated carbonation, obtained higher carbonation rates for higher cement content levels. Loo et al. (8) did not find differences in carbonation rates for concrete with diverse cement content levels. These authors (7-8) also used phenolphthalein to evaluate carbonation.

\subsection{Alkaline reserve influence in humidifying process}

After the carbonation, the presence of humidity controls the velocity of corrosion. In this paper, water absorption in the prismatic test specimens, where the rebars were, varied as humidifying and drying cycles took place but the corrosion intensities, measured in humid environments, continued to be proportional to the cement content. This also occurred in an environment with $100 \%$ relative humidity when the increase in mass due to water vapor penetration was almost the same for all test specimens no matter the cement content. The results suggest the need to research the transportation mechanism of mater to the interior of the test specimens, with the variation of cement content.

It is important to consider that this behavior may also be justified if the test specimens with larger cement content did not carbonate completely even though there was indication of total carbonation in the cylindrical test specimens with phenolphthalein. When this occurs in humid environments the calcium hydroxide in the carbonate dissolves itself and goes to the rebar region increasing the $\mathrm{pH}$ of the aqueous phase and contributing to a possible re-passivity (1), which might justify the lower intensity values of rebar corrosion in those test specimens. 


\section{CONCLUSIONES}

La intensidad de corrosión de las armaduras embebidas en morteros de distintos contenidos de cemento con la relación agua/cemento 0,6 fue analizada a través de la técnica de $\mathrm{Rp}$ y las alteraciones de la microestructura observadas por PIM, e indirectamente por la absorción capilar. Se puede concluir que:

a) La alteración de contenido en cemento, para una misma relación agua/cemento, alteró la microestructura del mortero;

b) Hay una alteración de la microestructura por la carbonatación de los morteros;

c) El periodo de iniciación de la corrosión, cuando las probetas se sometieron a la carbonatación, fue menor para las armaduras protegidas con morteros con menor contenido en cemento;

d) La intensidad de corrosión después de la despasivación de las armaduras fue inversamente proporcional al contenido en cemento;

e) La intensidad de corrosión no fue proporcional a la cantidad de agua absorbida.

\section{CONCLUSIONS}

The corrosion intensity of rebars embedded in mortars with different cement content levels and the same water/cement ratio was analyzed using the polarization resistance technique and the micro-structural alterations by mercury porosymetry and indirectly by capillary absorption. One may conclude that:

a) the alteration in the cement content, for the same water/cement ratio altered the mortar's microstructure;

b) the mortar microstructure was altered by the carbonation;

c) the initiation period by the corrosion, when the test specimens were submitted to carbonation, is shorter for rebars protected by mortars with a lower cement content;

d) the corrosion intensity after the loss of passivity by the rebars was inversely proportional to the cement content;

e) The corrosion intensity was not proportional to the amount of water absorbed.

\section{BIBLIOGRAFÍA}

(1) K. Tuutti. Corrosion of steel in concrete. p. 469, Swedish Cement and Concretc Research Institute, Stockholm, 1982.

(2) P. K. Mehta and P. J. M. Monteiro. Concreto: estrutura, propriedades e matcriais. p573 Editora Pini, 1Ed, São Paulo, 1994 (in portuguese).

(3) M. Hamada: Neutralization of concrete and corrosion of reiforcing steel. $5^{\text {th }}$ Int. Symp. on Chemistry of Cement. Tokyo (1968) pp. 343-368.

(4) V.G.Papadakis, C.G.Vayenas and M.N. Fardis: Fundamental modeling and experimental investigation on concrete carbonation. ACI Mat. Journal, Vol. 88 n $^{\circ} .2$ (1991) pp. 186-196.

(5) D. N. Winslow, M. D. Cohen, D.P. Bentz, K.A.Snyder and E.J.Garboczi: Percolation and Pore Structure in Mortars and Concrete, Cem. and Conc.Res., Vol. 24 (1994), pp. 25-37

(6) P. R. L Helene,. "Contribuição ao estudo da corrosão em armaduras de concreto armado". Tese de Livre DocênciaEsc.Politécnica, Univ.de São Paulo, São Paulo,1993 (in portuguese).

(7) N. R. Buenfeld, E.Okundi: Effect of cement content on transport in concrete. Magazine of Concrete Research, Vol. $50, \mathrm{n}^{\circ} 4$ (1998), pp. 339-351

(8) Y. H Loo,.M.S. Chin, C. T. Tam,. and C. G. Ong: A carbonation prediction model for accelerate carbonation testing of concrete. Magazine of Concrete Research, Vol. 46, nº 168 (1994), pp. 191-200.

(9) D. W. S. Ho and R. K.Lewis: Carbonation of concrete and its prediction. Cement and Concrete Research. Vol. 17 (1987), pp. 489-504.

(10) C. Alonso y C. Andrade: Effect of cement type ande cement proportion in the corrosion rate of rebars embedded in carbonat mortar. Materiales de Construccion, Vol. 37, n. 205 (1987) pp. 5-15.

(11) C. Andrade, C. Alonso and J.A. Gonzalez: A initial effort to use the corrosion rate measurements for estimating rebar durability. Corrosion Rates of Stcel in Concrete, ASTM STP 1065 (1990). 29.

(12) E. Bauer. Avaliação comparativa da influência da adição de escória de alto forno na corrosão de armaduras através de técnicas eletroquímicas. 236p. Tese de Doutorado - Escola Politécnica da Universidade de São Paulo. São Paulo, 1995 (in portuguese).

(13) P. O. A. Pessôa. Avaliação da influência do consumo de cimento na corrosão de armaduras de concreto carbonatadas. p. 153 , Publicação E.DM-04A/2002, Universidade de Brasília, 2002 (in portuguese).

(14) E. C. B. Monteiro. Estudo da capacidade de proteção de alguns tipos de cimentos nacionais, em relação à corrosão de armaduras sob a ação conjunta de $\mathrm{CO}_{2}$ e íons cloretos,Publicação EDM-004A/96 p. 138-Universidade de Brasília, Brasília-I)F,. 1996 (in portuguese).

(15) E. A. Guimarães. Avaliação da capacidade protetora de óleo de mamona contra a penetração de agentes agressivos no concreto. p139, Publicação E.DM-008 1/97-Universidade de Brasília. Brasília - DF,1997 (in portuguese).

(16) E. Bauer, A.A Nepomuceno. E. Pozzan, Caracterização da estrutura de poros em microestruturas carbonatadas, e sua relação com alguns mecanismos de transportes. In: Workdur - II Workshop sobre Durabilidade das Construções. ()., Anais de discussão. S. J. dos Campos São Paulo, Brasil, 2001, pp. 301-311 (in portuguese). 


\section{BIBLIOTECA DEL IETCC}

\section{RECURSOS DE INFORMACIÓN PARA EL ÁREA DE INGENIERÍA, ARQUITECTURA Y CONSTRUCCIÓN}

La Biblioteca del Instituto de Ciencias de la Construcción Eduardo Torroja (http://www.ietcc.csic.es/ biblioteca.html) creada desde la fundación del Instituto en el año 1952, está integrada dentro de la red de bibliotecas del CSIC (http://www.csic.es/cbic/cbic.htm). Es una biblioteca de investigación especializada en temas de ingeniería, arquitectura, construcción, ciencias de los materiales, normativa, etc. Su fondo bibliográfico está formado por más de 19.000 volúmenes y 684 títulos de revistas nacionales y extranjeras, disponible dentro de los Catálogos Informatizados de las Bibliotecas del CSIC (http://sauco.csic.es:4505/ALEPH). Integra también este fondo la colección de "Monografias del Instituto Eduardo Torroja" con 400 títulos publicados y un fondo especializado de folletos, cartillas y manuales que recogen trabajos de investigación especializados en el área de la ingeniería, arquitectura y construcción.

Su sala cuenta con 10 puestos de lectura y dispone de 3 ordenadores para consulta de bases de datos, catálogos, revistas electrónicas y recursos de información científica en Internet

La biblioteca ofrece sus servicios de información a la comunidad científica española y profesionales del área de la ingeniería, arquitectura y construcción.

\section{Servicios de referencia e información bibliográfica:}

Acceso a la información electrónica:

Catálogos CIRBIC: (http://www.csic.es/cbic/acceso.htm)

Bases de Datos de la Red de CD-ROM del CSIC

Revistas Electrónicas

Acceso a la información especializada disponible en Internet:

Servicio de búsquedas bibliográficas:

Este servicio facilita la obtención de referencias bibliográficas sobre cualquier tema de interés para el usuario.

\section{Servicio de suministro de documentos:}

\section{Obtención de Documentos:}

Búsqueda y suministro de artículos, libros, normas, manuales, etc. Además del envío de documentos por medios convencionales (correo, fax, etc.) la biblioteca del Instituto dispone de un servicio de envío de documentos por correo electrónico.

Para más información sobre los servicios y tarifas de los mismos:

imendoza@ietcc.csic

Bib_Torroja@bib.csic.es

http://www.ietcc.csic.es/biblioteca.html 